\title{
Mechanism of Propionate Formation by Selenomonas ruminantium, a Rumen Micro-organism
}

\author{
By M. J. B. PAYNTER* AND S. R. ELSDEN $\dagger$ \\ A.R.C. Unit for Microbiology, Department of Microbiology, \\ University of Sheffield, Western Bank, Sheffield, Sro 2 TN
}

(Accepted for publication 24 November 1969)

\begin{abstract}
SUMMARY
The mechanism of propionate formation by two strains of Selenomonas ruminantium has been investigated using substrates specifically labelled by ${ }^{14} \mathrm{C}$. Both strains behaved similarly. When $\left[2-{ }^{14} \mathrm{C}\right]$ lactate was fermented, the label in propionate was completely randomized in carbons 2 and 3 . When cells were grown on lactate in the presence of ${ }^{14} \mathrm{CO}_{2}$, label was fixed exclusively into propionate carboxyl. The results are consistent with propionate being formed by the 'succinate' pathway.
\end{abstract}

\section{INTRODUCTION}

Selenomonas ruminantium was first isolated by Bryant (1956) from rumen contents of cattle which had been fed on a ration high in soluble carbohydrates. The bacterium, which was a significant member of the microbial population, fermented glucose, with the formation of lactate, acetate and propionate. Some strains also fermented lactate to yield acetate and propionate. Thus, under certain conditions, S. ruminantium probably plays an important role in the production of propionate, the only major rumen fermentation product known to be glycogenic. For these reasons the mechanism of propionate formation in $S$. ruminantium was studied.

At present the 'succinate' and 'direct reduction' pathways are the two known mechanisms for fermentation of lactate to propionate. The 'succinate' pathway involves heterotrophic fixation of $\mathrm{CO}_{2}$ to form succinate (Wood \& Werkman, I936; Wood, Werkman, Hemingway \& Nier, 1940, 194I; Johns, I95I $b$ ) and this is subsequently decarboxylated to propionate (Delwiche, I948; Johns, I949, I95I $a, b, c)$. In the 'direct reduction' pathway the carbon skeleton of lactate remains intact when it is converted to propionate (Johns, 1952; Lewis \& Elsden, 1955; Ladd \& Walker, 1959). These two pathways can be distinguished by fermenting $\left[2-{ }^{14} \mathrm{C}\right]$ lactate and determining the labelling pattern of the propionate produced. Propionate formed via the 'direct reduction' pathway will be $\left[2-{ }^{14} \mathrm{C}\right]$ propionate, whereas propionate formed by the 'succinate' mechanism will be a mixture of $\left[2-^{14} \mathrm{C}\right]$ propionate and $\left[3^{-14} \mathrm{C}\right]$ propionate, which will degrade as $\left[2-3^{14} \mathrm{C}\right]$ propionate, carbons 2 and 3 having equal activity. The pathways can also be identified by fermenting lactate in the presence of ${ }^{14} \mathrm{CO}_{2}$. The 'succinate' mechanism will produce $\left[\mathrm{I}^{-14} \mathrm{C}\right]$ propionate, whereas no radioactivity will

* Present address: Microbiology Section, Division of Biology, Long Hall, Clemson University, Clemson, South Carolina 2963r, U.S.A.

$\dagger$ Present address: A.R.C. Food Research Institute, Colney Lane, Norwich, Norfolk, NOR $70 F$.

Vol. 6o, No. 3 was issued I3 May 1970 
appear in propionate if it arises via the 'direct reduction' pathway. Such experiments have been performed with two lactate-fermenting strains of Selenomonas ruminantium and the results are presented here.

\section{METHODS}

Organisms and cultural procedure. Strains HD4 and PCI 8 of Selenomonas ruminantium were obtained from Dr M. P. Bryant. They were maintained in test-tubes in a sloppy agar medium containing $\mathrm{I} \%(\mathrm{w} / \mathrm{v})$ sodium DL-lactate, $\mathrm{I} \cdot 5 \%(\mathrm{w} / \mathrm{v})$ Oxoid tryptone, $0.5 \%(\mathrm{w} / \mathrm{v})$ Difco yeast extract, $0.000 \mathrm{I} \%(\mathrm{w} / \mathrm{v})$ resazurin, $0.02 \%(\mathrm{v} / \mathrm{v})$ thioglycollic acid, $0.2 \%(\mathrm{w} / \mathrm{v})$ Davies New Zealand agar and $0 . x \mathrm{M}-\mathrm{phosphate} \mathrm{buffer}$ $\left(\mathrm{KH}_{2} \mathrm{PO}_{4}-\mathrm{NaOH}\right), \mathrm{pH} 6 \cdot 8$, in distilled water, equilibrated with $\mathrm{CO}_{2}$ at approximately $40^{\circ}$. All ingredients were sterilized together by autoclaving ( $12 \mathrm{I}^{\circ}, 15 \mathrm{~min}$.). Cultures were kept anaerobic by placing an alkaline pyrogallol plug at the top of the tube, which was then closed with a rubber stopper. Cultures were incubated at $37^{\circ}$ for 10 to I $6 \mathrm{hr}$ and then stored at o to $5^{\circ}$. Stock cultures were transferred weekly.

Analytical methods. DL-lactate was estimated by the ceric sulphate method of Elsden \& Gibson (1954). The growth medium contained interfering substances which were not completely removed by copper-lime treatment. To overcome this, lactate was quantitatively extracted from the medium with $150 \mathrm{ml}$. freshly distilled ether by the procedure described by Knight (I962). To the ethereal extract were added $2 \mathrm{ml}$. of $10 \%$ (w/v) $\mathrm{Na}_{2} \mathrm{CO}_{3}$, the ether was distilled off and the residue evaporated to approximately $0.5 \mathrm{ml}$.

Total volatile fatty acid content of a fermentation fluid was measured by titrating a steam distillate with $\mathrm{CO}_{2}$-free $0 . \mathrm{I} N-\mathrm{NaOH}$ in a stream of $\mathrm{CO}_{2}$-free air; phenol red was the indicator. When samples contained lactate the distillate was acidified with $\mathrm{H}_{2} \mathrm{SO}_{4}$ (final concentration $\mathrm{O} \cdot \mathrm{I} \mathrm{N}$ ) and redistilled over magnesium sulphate as described by Friedemann (1938).

Individual volatile acids in a mixture were identified and estimated by gas liquid chromatography (g.l.c.) using an apparatus with a manually operated recording burette (James \& Martin, I952). The liquid phase was silicone DC 550-stearic acidorthophosphoric acid mixture supported on acid-washed celite (James \& Martin, 1952). The major difficulty in quantitative estimation of volatile fatty acids by g.l.c. has been the addition of the sample to the column. At the beginning of this work we were introduced by Dr A. T. Johns (at that time Director of the D.S.I.R. Plant Chemistry Division, Palmerston North, New Zealand) to a simple and effective technique which had been developed in New Zealand and which, to our knowledge, has not previously been described. The steam distillate, after titration to measure total volatile fatty acid content, was made alkaline by addition of approximately $\mathrm{I} \cdot 0 \mathrm{ml}$. $0.01 \mathrm{M}-\mathrm{NaOH}$ and evaporated down in a steam bath to a volume such that the volatile fatty acid concentration was no more than $0.8 \mathrm{~m}$-equiv. $/ \mathrm{ml}$. A volume of this concentrated solution, not exceeding $30 \mu \mathrm{l}$., was placed in a porcelain combustion boat $(3 \mathrm{~mm} . \times 66 \mathrm{~mm}$.) and spread along the bottom of the boat to form a thin film of liquid. If the volume of liquid exceeded $30 \mu \mathrm{l}$. subsequent separation of the fatty acids was impaired due to formation of azeotropic mixtures. One end of the boat was then lodged in the mouth of the column and evenly and swiftly filled with a mixture ( 2 vol. +3 vol.) of powdered sodium bisulphate and acid-washed celite 535 . The boat, when full, was pushed into the column and the gas supply connected. After standing 
for $5 \mathrm{~min}$. the gas supply $\left(\mathrm{O}_{2}\right.$-free nitrogen) was turned on. During the $5 \mathrm{~min}$. period the boat and its contents reached the temperature $\left(100^{\circ}\right)$ of the column and acids diffused into the gas phase. Sodium bisulphate liberates the acids, but if it is used alone a crystalline mass is formed which occludes a significant amount of the acids, thus lowering the recoveries.

Additional celite results in the formation of a porous mass which does not retain the acids. The sodium bisulphate + celite mixture was dried at $150^{\circ}$ for $2 \mathrm{hr}$ and stored in a glass-stoppered bottle.

Because the volume of sample added to the column was not measured accurately, the record of the analysis obtained was used to calculate the percentage composition of the mixture; the amounts of individual acids were then calculated from the value for the total volatile acid content of the sample obtained by titration of the distillate. Recoveries for acetic, propionic and butyric acid were $\pm 4 \%$ for each acid.

Measurement of radioactivity. Samples to be counted were converted to $\mathrm{CO}_{2}$ which was plated as $\mathrm{BaCO}_{3}$ (Sakami, I955; Knight, I962). Barium carbonate plates were counted with a Packard model 200A gas-flow counter (Packard Instruments, La Grange, Ill., U.S.A.) operated under the conditions described by Knight (1962). Activities, corrected for background ( 20 to 28 c.p.m.), were expressed as counts per minute at infinite thinness. The total radioactivity of a sample was determined after wet combustion (Sakami, I955; Knight, I962).

Degradations. Acetate and propionate were degraded by the Schmidt reaction (Sakami, 1955; Ladd, 1959). Sample and sulphuric acid were cooled in ice-water, prior to mixing, and activated sodium azide added to the cold reaction mixture. The reaction vessel was then quickly attached to the degradation train. The $\mathrm{CO}_{2}$ produced was measured manometrically in a Warburg apparatus. The strongly acid reaction mixture, containing the amine produced by the reaction, was transferred to a Markham (I942) still, made alkaline with $\mathrm{IO} \mathrm{N}-\mathrm{NaOH}$ (5 ml.) and steam-distilled into $\mathrm{N}-\mathrm{H}_{2} \mathrm{SO}_{4}(2 \mathrm{ml}$.). The amine sulphate was taken to dryness and combusted.

The $\mathrm{CO}_{2}$ produced was measured manometrically and counted as barium carbonate. The yield of amine was calculated from the amount of $\mathrm{CO}_{2}$ formed by combustion. In some experiments with propionate the ethylamine produced by the Schmidt degradation was oxidized to acetate with alkaline potassium permanganate (Sakami, I955). The acetate thus formed was recovered by steam distillation, and after titration with $\mathrm{N}-\mathrm{NaOH}$ the degradation by the Schmidt procedure was repeated.

Reagents. Sodium DL-lactate was prepared by neutralizing boiling AnalaR DL-lactic acid. Amberlite CG-50 resin, methyl ethyl ketone, ceric sulphate, thioglycollic acid and sodium azide were all of laboratory reagent grade (British Drug Houses Ltd., Poole, Dorset). Amberlite CG-50 was fractionated by sedimentation; that portion sedimenting from an aqueous suspension through a height of $17 \mathrm{~cm}$. in $5 \mathrm{~min}$. being used. Resazurin, silicone fluid DC 550 and stearic acid were from Hopkin \& Williams Ltd. Celite 535 was from Johns-Manville (London). Acetone (May \& Baker Ltd., Dagenham, Essex) was redistilled. Sodium DL[2- $\left.{ }^{14} \mathrm{C}\right]$ lactate and $\mathrm{Na}_{2}{ }^{14} \mathrm{CO}_{3}$ were from the Radiochemical Centre, Amersham. All other reagents were of AnalaR grade.

Experimental procedures. Procedures for fermenting $\mathrm{DL}\left[2-{ }^{14} \mathrm{C}\right]$ lactate and lactate plus $\mathrm{Na}_{2}{ }^{14} \mathrm{CO}_{3}$ were similar in both cases. Approximately $40 \mathrm{ml}$. cultures were grown under $\mathrm{CO}_{2}$ in the medium described above (minus agar), in micro-kjeldahl flasks. After inoculation, a sterile solution of sodium $\mathrm{DL}\left[2-{ }^{14} \mathrm{C}\right]$ lactate (Io $\mu$ mole: $2 \mu \mathrm{c}$ ) or 
$\mathrm{Na}_{2}{ }^{14} \mathrm{CO}_{3}$ (100 $\mu$ mole) was added. When labelled lactate was used a sample of medium was taken for the estimation of lactate. Vessels were sealed and incubated at $37^{\circ}$ until heavy growth was observed, after which cells were centrifuged off and their radioactivity measured. A sample of the supernatant was set aside for estimation of acetate and propionate. Other samples were steam-distilled, neutralized with $0 \cdot \mathrm{I} \mathrm{N}-\mathrm{NaOH}$, and evaporated to dryness. The residues were dissolved in $0.2 \mathrm{ml}$. of a mixture of methyl ethyl ketone, acetone and water $(\mathrm{I}+2+9$ by vol.), and the volatile acids fractionated on a column of Amberlite CG-50 resin (Seki, 1958). Acetate and propionate fractions eluted from the column were titrated with $0 \cdot 1 \mathrm{~N}-\mathrm{NaOH}$ and taken to dryness. The residues were dissolved in water. A portion of each was assayed for volatile acid by steam distillation and titration and a second portion, after mixing with sufficient succinic acid to give a total of $600 \mu$ atoms of carbon, was combusted and the radioactivity measured. The appropriate unlabelled acid was added to a third portion to bring the total acid content to approximately $2 \mathrm{~m}$-mole. The new specific activity was measured, and about I m-mole of acid was degraded by the Schmidt reaction, the specific activity of each carbon being determined.

Table I. Radioactivity fixed into products when strains HD4 and PCI8 of Selenomonas ruminantium were grown on DL-lactate in the presence of $\mathrm{Na}_{2}{ }^{14} \mathrm{CO}_{3}$

Cultures were grown for 4 days at $37^{\circ}$. At start each culture contained $100 \mu$ mole $\mathrm{Na}_{2}{ }^{14} \mathrm{CO}_{3}$; $3.46 \times 10^{6}$ c.p.m. Values given are per culture volume.

Volume of culture (ml.)

Radioactivity in cells (c.p.m.)

Total volatile acids formed ( $\mu$ mole)

Total activity in volatile fatty acids (c.p.m.)

Specific activity of volatile fatty acids (c.p.m.) umole)

Acetate formed ( $\mu$ mole)

Activity of acetate (c.p.m.)

Specific activity of acetate (c.p.m. $/ \mu$ mole)

Propionate formed ( $\mu$ mole)

Activity of propionate (c.p.m.)

Specific activity of propionate (c.p.m. $/ \mu$ mole)

\begin{tabular}{ll}
\multicolumn{1}{c}{ PD4 } & \multicolumn{1}{c}{ PCI8 } \\
$36 \cdot 5$ & 41.4 \\
$5.00 \times 10^{3}$ & $1.53 \times 10^{3}$ \\
1,050 & 983 \\
$4.92 \times 10^{5}$ & $2 \cdot 06 \times 10^{5}$ \\
469 & \\
387 & 210 \\
$7 \cdot 24 \times 10^{3}$ & 388 \\
18.7 & $1 \cdot 16 \times 10^{3}$ \\
660 & 3.0 \\
$4.80 \times 10^{5}$ & 595 \\
728 & $1.95 \times 10^{5}$ \\
& 328
\end{tabular}

\section{RESULTS AND DISCUSSION}

Cultures of strains HD4 and PCr8 were grown on DL-lactate in the presence of $\mathrm{Na}_{2}{ }^{14} \mathrm{CO}_{3}$, and fermentation products were examined for radioactivity (Table I). Both strains fixed ${ }^{14} \mathrm{CO}_{2}$ into cell material and volatile fatty acid fraction. Of the isotope fixed into volatile fatty acid $97.6 \%$ (HD4) and $94.8 \%$ (PCI8) was located in propionate. No significant activity was found in acetate. Degradation of the propionate showed, in both cases, that the specific activity of the carboxyl group was similar to that of the undegraded propionate, and no significant activity was present in carbons 2 and 3 (Table 2). Thus the ${ }^{14} \mathrm{CO}_{2}$ fixed into propionate was located exclusively in the carboxyl group.

Cultures were grown on DL-lactate in the presence of $\mathrm{DL}\left[2-{ }^{14} \mathrm{C}\right]$ lactate. The amounts of radioactivity found in fermentation products are shown in Table 3. One point four per cent or less of the added lactate-label was found in cells, whereas 103\% (HD4) and 
$20 \%$ (PCI 8 ) were located in volatile fatty acid. In both experiments approximately $62 \%$ of the volatile fatty acid-label was in propionate and $43 \%$ in acetate. However, the specific activities of acetate and propionate were approximately equal.

Degradation of acetate produced by the two strains showed, in each case, that the specific activities of the carboxyl group and undegraded acetate were similar (Table 4).

Table 2. Distribution of radioactivity in propionate produced by the fermentation of DL-lactate in the presence of $\mathrm{Na}_{2}{ }^{14} \mathrm{CO}_{3}$ by $\mathrm{S}$. ruminantium strains HD4 and PCI8

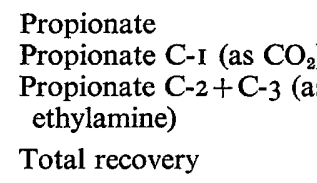

\begin{tabular}{|c|c|c|c|}
\hline \multicolumn{2}{|c|}{ Strain HD4 } & \multicolumn{2}{|c|}{ Strain PCI 8} \\
\hline $\begin{array}{l}\text { Specific } \\
\text { activity } \\
\text { (c.p.m./ } \\
\mu \text { mole) }\end{array}$ & $\%$ of label & $\begin{array}{l}\text { Specific } \\
\text { activity } \\
\text { (c.p.m./ } \\
\mu \text { mole) }\end{array}$ & $\%$ of label \\
\hline $37 \cdot 6$ & (100) & 13.7 & (IOO) \\
\hline $38 \cdot 4$ & 102 & 15.6 & I I 4 \\
\hline 0.17 & 0.5 & 0.29 & 2 \\
\hline 一 & 103 & 一 & II 6 \\
\hline
\end{tabular}

Table 3. Radioactivity fixed into products when strains HD4 and PCI8 of $S$. ruminantium were grown on $D L\left[2-{ }^{14} C\right]$ lactate

Cultures were grown for $2(\mathrm{HD} 4)$ and 6 (PCI 8 ) days at $37^{\circ}$. At the start, HD4-culture contained $6 \mathrm{I} \cdot 0 \mu$ mole DL-lactate $/ \mathrm{ml}$., specific activity 370 c.p.m. $/ \mu$ mole; PC I 8 -culture contained $68.5 \mu$ mole DL-lactate $/ \mathrm{ml}$., specific activity 307 c.p.m. per $\mu$ mole. Values given are per culture volume.

Volume (ml.)

Radioactivity in cells (c.p.m.)

Total volatile acids formed ( $\mu$ mole)

Total activity in volatile fatty acids (c.p.m.)

Specific activity of volatile fatty acids (c.p.m./ $/ \mu$ mole)

Acetate formed ( $\mu$ mole)

Activity of acetate (c.p.m.)

Specific activity of acetate (c.p.m./ $\mu$ mole)

Propionate formed ( $\mu$ mole)

Activity of propionate (c.p.m.)

Specific activity of propionate (c.p.m. $/ \mu$ mole)

\begin{tabular}{ll}
$\overbrace{\mathrm{HD} 4}$ Strain & \multicolumn{1}{c}{ PCI 8} \\
$34 \cdot 2$ & 34.5 \\
11,200 & 396 \\
2,410 & 724 \\
$7 \cdot 96 \times 10^{5}$ & $14.3 \times 10^{4}$ \\
330 & 198 \\
930 & 296 \\
$3.27 \times 10^{5}$ & $6.41 \times 10^{4}$ \\
352 & 217 \\
1,480 & 428 \\
$5.03 \times 10^{5}$ & $8.94 \times 10^{4}$ \\
340 & 209
\end{tabular}

Table 4. Distribution of radioactivity in acetate produced by the fermentation of $D L\left[2-{ }^{14} C\right]$ lactate by $S$. ruminantium strains HD4 and PCI8

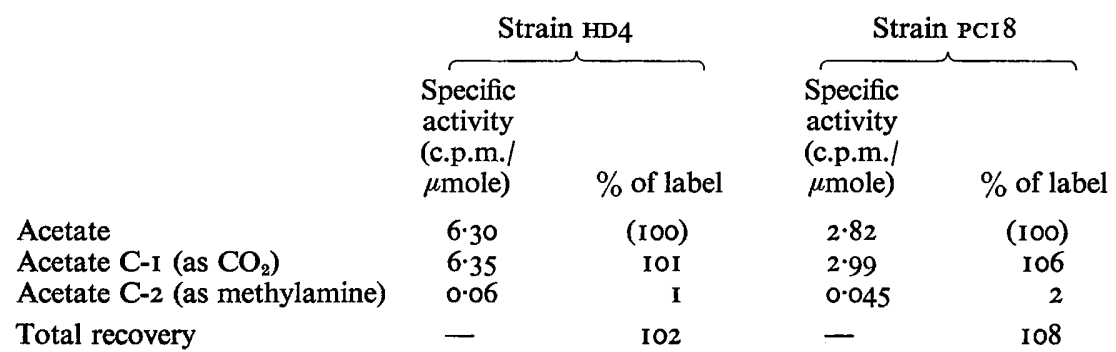


No significant activity was present in the methyl group. Thus, $\left[2{ }^{14} \mathrm{C}\right]$ lactate gave rise to $\left[\mathrm{I}-{ }^{14} \mathrm{C}\right]$ acetate.

Table 5 shows results obtained when the two samples of propionate were degraded. The same labelling pattern was produced by both organisms. No activity was found in the carboxyl group. Carbons 2 and 3 were approximately equally labelled, and the sum of their specific activities was approximately equal to the specific activity of the undegraded propionate. Thus, $\left[2-{ }^{14} \mathrm{C}\right]$ lactate gave rise to $\left[2-3^{-14} \mathrm{C}\right]$ propionate.

Table 5. Distribution of radioactivity in propionate produced by the fermentation of $D L\left[2{ }^{14} C\right]$ lactate by $S$. ruminantium strains HD4 and PCI8

\begin{tabular}{|c|c|c|c|c|}
\hline & \multicolumn{2}{|c|}{ Strain HD4 } & \multicolumn{2}{|c|}{ Strain PCI8 } \\
\hline & $\begin{array}{l}\text { Specific } \\
\text { activity } \\
\text { (c.p.m./ } \\
\mu \text { mole) }\end{array}$ & $\%$ of label & $\begin{array}{l}\text { Specific } \\
\text { activity } \\
\text { (c.p.m./ } \\
\mu \text { mole) }\end{array}$ & $\%$ of label \\
\hline Propionate & $13 \cdot 3$ & (100) & $4 \cdot 7 \mathrm{I}$ & (100) \\
\hline Propionate C-I (as $\mathrm{CO}_{2}$ ) & 0 & ó & 0 & ó \\
\hline Propionate $\mathrm{C}-2$ as $\left(\mathrm{CO}_{2}\right)$ & 6.92 & 52 & $2 \cdot 44$ & 52 \\
\hline $\begin{array}{l}\text { Propionate C-3 (as methyl- } \\
\text { amine) }\end{array}$ & 6.59 & 50 & $2 \cdot 35$ & 50 \\
\hline Total recovery & - & 102 & - & 102 \\
\hline
\end{tabular}

The results obtained are thus consistent with the hypothesis that Selenomonas ruminantium forms propionate via the 'succinate' pathway and acetate by the direct oxidation of lactate.

This investigation was supported by grants from the Department of Scientific and Industrial Research and the Agricultural Research Council.

\section{REFERENCES}

BRYANT, M. P. (1956). The characteristics of strains of Selenomonas isolated from bovine rumen contents. Journal of Bacteriology 72, 162.

Delwiche, E. A. (1948). Mechanism of propionic acid formation by Propionibacterium pentosaceum. Journal of Bacteriology 56, $8 \mathrm{I}$.

ElsDeN, S. R. \& Gibson, Q. H. (1954). The estimation of lactic acid using ceric sulphate. Biochemical Journal $\mathbf{5 8}$, I 54 .

FrIEDEMANN, T. E. (1938). Identification and quantitative determination of volatile alcohols and volatile acids. Journal of Biological Chemistry 123, 161.

JAmes, A. T. \& MARTIN, A. J. P. (1952). Gas-liquid partition chromatography: the separation and micro-estimation of volatile fatty acids from formic to dodecanoic acid. Biochemical Journal 5o, 679.

Johns, A. T. (1949). Mechanism of propionic acid formation in bacterial fermentation. Nature $\mathbf{1 6 4}$, 620.

JoHNS, A. T. (I $95 \mathrm{I} a$ ). Isolation of bacterium producing propionic acid from the rumen of sheep. Journal of General Microbiology 5, 317.

JoHns, A. T. (195 $\mathrm{I} b$ ). The mechanism of propionic acid formation by Veillonella gazogenes. Journal of General Microbiology 5, 326.

JoHns, A. T. (I95I c). The mechanism of propionic acid formation by Propionibacteria. Journal of General Microbiology 5, 337.

JoHns, A. T. (1952). Mechanism of propionate formation by Clostridium propionicum. Journal of General Microbiology 6, I23. 
KNIGHT, M. (1962). The photometabolism of propionate by Rhodospirillum rubrum. Biochemical Journal 84, 170.

LADD, J. N. (I959). The fermentation of lactic acid by a Gram-negative coccus. Biochemical Journal 7I, I 6.

LADD, J. N. \& WALKER, D. J. (1959). The fermentation of lactate and acrylate by the rumen microorganism L.C. Biochemical Journal 7r, 364.

LewIS, D. \& ElSDEN, S. R. (I955). The fermentation of L-threonine, L-serine, L-cysteine and acrylic acid by a Gram-negative coccus. Biochemical Journal 6o, 683 .

MARKHAM, R. (1942). A steam distillation apparatus suitable for micro-kjeldahl analysis. Biochemical Journal 36, 790.

SAKAMI, W. (1955). Handbook of Isotope Tracer Methods. Cleveland, Ohio, U.S.A.: Western Reserve University.

SEKI, T. (1958). Chromatographic separation of lower fatty acids. Journal of Biochemistry 45, 855.

Wood, H. G. \& WERKMAN, C. H. (I936). The utilization of $\mathrm{CO}_{2}$ in the dissimilation of glycerol by the propionic acid bacteria. Biochemical Journal 30, 48.

Wood, H. G., Werkman, C. H., Hemingway, A. \& Nier, A. O. (I940). Heavy carbon as a tracer in bacterial fixation of carbon dioxide. Journal of Biological Chemistry 135, 789.

Wood, H. G., Werkman, C. H., Hemingway, A. \& Nier, A. O. (I94I). Heavy carbon as a tracer in heterotrophic carbon dioxide assimilation. Journal of Biological Chemistry r39, 365. 